\title{
Verklarende lys van plantpatologiese terme
}

\author{
G.J.M.A. Gorter \\ Navorsingsinstituut vir Plantbeskerming, Pretoria
}

\section{INLEIIDING}

Die vinnige ontwikkeling van plantpatologie as wetenskap het aanleiding gegee tot die gebruik van 'n reeks terme wat nie altyd op die korrekte wyse aangewend word nie. Om hierdie probleem te oorkom het komitees in die V.S.A. en in Engeland en Nederland verklarende lyste opgestel om dic betekenis van plantsicktekundige terme soveel moontlik te standaardiseer.

In Suid-Afrika is weliswaar 'n lys opgestel van sleutelterme wat veral vir die vrugtebedryf van belang is (Matthee \& Thomas, 1976) maar dit het egter 'n leemte gelaat met betrekking tot lokale gebruiksterme vir ander aspekte van die plantpatologic. Dikwels is selfs geen ekwivalente name vir oorsese terme in Afrikaans beskikbaar nie. Om in hierdie leemtes te voorsien is die volgende lys opgestel in die hoop dat gebruikers daarvan die terme verstaanbaar sal vind.

Dit is moontlik dat party definisies nie algemeen ingang sal vind nie. Die onus berus dan by die gebruiker om sy siening van in bepaalde term duidelik te definieer. Wetenskaplike taalgebruik is nie staties nie en dit is dan ook wel moontlik dat bepaalde terme van tyd tot tyd aan ontwikkelende insigte aangepas moet word.

Die lys mak nie aanspraak op volledigheid nie. Derhalwe sal die skrywer in hierdie verband graag voorstelle en wenke ontvang om met die verloop van tyd 'n hersiening van die lys moontlik te maak.

Die terme is in die lys alfabeties gerangskik en vetgedruk waar dit beskryf word. Sinonieme is nie vetgedruk nie, maar verwys na die wenslike terme. Waar 'n gedefinieerde term elders in dic teks aangehaal word, is dit gekursiveer die eerste keer wat dit so gebruik word.

Beskrywings van terme van verwante vakke soos Mikologie, Mikrobiologie, Virologie en Ingenieurswese is soveel moontlik vermy om duplikasie met ander lyste te voorkom. 'n Alfabetiese lys van ekwivalente Engelse plantpatologiese terme is bygevoeg sonder om dit weer in Engels te omskryf, aangesien sulke beskrywings elders beskikbaar is (sien literatuurlys, veral CAB. Phytopathological Paper no. 17, 1973.)

\section{ALFABETIESE LYS}

Aanjaer ("Incitant") - Een of ander faktor wat die patogenisiteit van 'n patogeen aanhelp. Dit word soms verkeerdelik gebruik om die oorsaak van 'n siekte aan te dui.

Aanpassing ("Adaptation") - 'n Nie-erflike of erflike verandering van 'n organisme onder ongunstige groeitoestande, wat die organisme in staat stel om te oorleef en te vermenigvuldig.

Aarbandchlorose ("Vein banding") - 'n Kleurverandering in 'n noue sone blaarweefsel langs die hoofnerwe.
Aarverheldering ("Vein clearing") - Toenemende deurskynendheid van die bladaarstelsel wat veral by deurvallende lig sigbaar is.

Aërosol ("Acrosol") - 'n Fyn verdeelde suspensie of oplossing van 'n bestrydingsiniddel wat in newelvorm met 'n druppeldeursnee van $0,1-5 \mu \mathrm{m}$ versprei word.

Afloop ("Run-off") - Die afloop van surplus vloeistof vanaf ' $n$ bespuite oppervlakte nadat druppels van 'n spuitmengsel gedurende en onmiddellik na toediening saamvloei om 'n aaneenlopende laag te vorm.

Aftipeverwydering ("Roguing") - Die verwydering van ongesonde of ongewenste plante wat nie ras-eg is nie na kritiese inspeksie van 'n gewas.

Aggressiwiteit ("Aggressiveness") - Aantastingspotensiaal van ' $n$ ras van 'n patogeen wat in teenstelling met virulensie nie van ander rasse differensieerbaar verskil in die patologiese effek op 'n voedsterplantvarieteit nie, maar wat wel verskil in sy vermoë om te infekteer.

Aksenie ("Axeny") - Sien Passiewe weerstand.

Akseniese kultuur ("Axenic culture") - Die suiwer kultuur van 'n enkele spesie in die afwesigheid van ander organismes.

Aktiewe bestanddeel ("Active ingredient") - Die aktiewe komponent van 'n geformuleerde chemiese produk.

Aktiewe weerstand ("Active resistance") - Weerstand as gevolg van 'n afweerreaksie van die voedsterplant deur aanwesigheid van 'n patogeen of sy metaboliete.

Aktiveermiddel ("Activator") - 'n Stof wat aan 'n beheermiddel toegevoeg word om die toksisiteit daarvan direk of indirek te verhoog.

Akute simptome ("Acute symptoms") - (1) Strawwe simptome van siektes wat deur swamme en bakterieë veroorsaak word en gewoonlik tot afsterwe van plante of dele daarvan lei. (2) Skoksimptome wat by virussiektes veroorsaak word en direk na infeksie ontstaan, maar wat op later ontwikkelde blare verdwyn.

Anabiose ("Anabiosis") - 'n Fisiologiese toestand waarby die lewensprosesse van swam- en bakteriespore 'n baie lae, dikwels onmeetbaar minimale aktiwiteit vertoon. Kom ook voor by insekte en nematodes wat in 'n rustoestand verkeer.

Antagonisme ("Antagonism") - Die ongunstige invloed wat een organisme op ' $n$ ander, of verskillende organismes op mekaar, uitoefen. Gewoonlik is dit 'n groeibelemmerende effek.

Antagonis ("Antagonist") - Die organisme(s) wat by antagonisme betrokke is en 'n skadelike invloed uitoefen.

Antibiose ("Antibiosis") - Groeibelemmering van 'n mikro-organisme deur middel van 'n antibiotikum wat deur 'n ander mikro-organisme geproduseer word. 
Antibiotikum (“Antibiotic") - 'n Organiese stof wat deur lewende mikro-organismes gevorm word en wat die groei van ander mikro-organismes belemmer of hulle doodmaak.

Antimikotiese middel ("Anti-fungal substance") - 'n Substansie wat die groei van hifes en die ontkieming van swamspore inhibeer of stopsit.

Antisporulant ("Antisporulant") - 'n Stof wat die produksie van spore verminder of voorkom sonder om die vegetatiewe groei van die swam te benadeel.

Antraknose ("Anthracnose") - Gewone naam vir 'n plantsiekte wat gekenmerk word deur bruin of swart kolle op bogrondse plantdele wat veroorsaak word deur ongeslagtelike swamme (Fungi imperfecti) wat konidiums in aservuli produseer. Op vrugte gewoonlik ingesonke letsels.

Appressorium ("Appressorium") - Die opgeswelde punt van 'n hife wat ophou om te groei. Die bolvormige of eiervormige vorm van die appressorium vergroot die raakgebied tussen swam- en voedsterplantoppervlak. Dit is dikwels die punt waar 'n patogeen penetreer.

Atrofie ("Atrophy") - Die afwesigheid van, of onvolledige ontwikkeling van weefsels of organe as gevolg van afwesigheid van selvermeerdering of -vergroting.

Attenuasie ("Attenuation") - Vermindering in die vermoë van 'n patogeen om siekte te veroorsaak of vermindering van sy aggressiwiteit.

Avirulent ("Non-virulent") - Die aard van 'n variant van 'n patogene organisme wat nie in staat is om strawwe siekte te veroorsaak nie.

Bakterie ("Bacterium") - 'n Organisme wat gekenmerk is deur eenselligheid en vermeerdering as gevolg van splitsing.

Bakteriofaag ("Bacteriophage") - 'n Virus wat bakterieë infekteer en gewoonlik lise van bakterieselle veroorsaak.

Bakteriose ("Bacteriosis") - 'n Siekte of infeksie wat deur bakterieë veroorsaak word.

Bakterisied ("Backtericide") - 'n Middel wat bakterieë doodmaak.

Basnekrose ("Bark necrosis") - Lokale afsterwing van basweefsel by houtagtige plante. Ontwikkeling van 'n omlynende kurkweefsel of oorgroeiende wondkallus kan die afsterwing stuit.

Beaumont-periode ("Beaumont period") - 'n Periode van twee dae waartydens die temperatuur nie benede $10^{\circ} \mathrm{C}$ daal nie en die relatiewe vogtigheid $75 \%$ oorskrei, kondisies wat die ontwikkeling van laatroes by aartappels (Phytophthora infestans) begunstig.

Bedekking ("Coverage") - Die oppervlaktegedeelte van plante of plantdele waarop die materiaal wat toegedien word na bestuiwing of bespuiting behoue bly.

Beheer ("Control") - Die beperking van die slegte gevolge van 'n siekte tot 'n ekonomies aanvaarbare peil.

Beheermiddel ("Control agent") - Enige geformuleerde produk wat 'n toksiese komponent bevat waarmee plantsiektes beheer kan word.

Benattingsmiddel ("Wetting agent") - 'n Middel wat die oppervlaktespanning van 'n vloeistof op 'n gegewe oppervlakte verminder.

Benatbare poeier ("Wettable powder") - 'n Siektebestrydingsmiddel in poeiervorm wat met water gemeng kan word om 'n suspensie of oplossing te vorm.
Berokingsmiddel ("Fumigant") - 'n Chemiese bestrydingsmiddel wat in gas-, damp- of rookvorm toegedien word.

Beskadiging ("Injury") - Letsels wat deur klimaatsfaktore (hitte, droogte, hael ens.) gereedskap, bestrydingsmiddels of diere veroorsaak word.

Beskermmiddel ("Protectant") - 'n Stof wat 'n organisme teen infeksie deur 'n patogeen beskerm.

Beskermende swamdoder ("Protective fungicide") Swamdoder wat 'n organisme teen infeksie deur 'n swam beskerm.

Besmettingsdrumpelgetal ("Numerical threshhold of infection") - Die minimum getal infeksie-eenhede van 'n patogeen wat vereis word om besmetting van 'n plant onder gunstige toestande te laat plaasvind.

Besmettingsfokus ("Focus of infection") - Plek waar die besmetting plaaslik gekonsentreer is.

Bespuiting ("Spraying") - 'n Toedieningsmetode waartydens 'n beheermiddel wat opgelos of gesuspendeer is in 'n vloeistof, in die vorm van klein druppeltjies op oppervlaktes toegedien word. Die fisiese kenmerke van 'n bespuiting is onder andere afhanklik van die geaardheid van die dryfkrag (lug of water) en die druppelgroottes en hierdie faktore bepaal die volume van die spuitmengsel wat per gegewe oppervlakte toegedien word, byvoorbeeld:

(a) Hö̈ volume

Meer as 11201 spuitmengsel per ha op bome en bosse en meer as 670 I spuitmengsel per hektaar op grondgewasse.

(b) Mediumvolume

560-1120 I spuitmengsel per ha op bome en bosse en 225-670 I spuitmengsel per ha op grondgewasse.

(c) Laevolume

225-560 I spuitmengsel per ha op bome en bosse en 55-225 I spuitmengsel per ha op grondgewasse.

(d) Ultra-laevolume

Minder as 301 spuitmengsel per ha op bome en bosse en minder as 5,51 spuitmengsel per ha op grondgewasse.

Bestand, ("Resistant") - Die besit van kwaliteite wat die ontwikkeling van 'n bepaalde patogeen belemmer.

Bestandheid ("Resistance") - Sien Weerstand.

Bestryding ("Control") - Die verhindering, belemmering of eliminasie van 'n siekte.

Bestrydingsmiddel ("Control agent") - Enige geformuleerde produk wat 'n toksiese komponent bevat waarmee plantsiektes bestry kan word.

Bestuiwing ("Dusting") - 'n Toedieningsmetode waarmee 'n beheermiddel in 'n poeiervorm op oppervlaktes toegedien word.

Binnedringing ("Invasion") - Die deurdring en kolonisasie van 'n voedsterplant deur 'n organisme.

Biologiese beheer ("Biological control") - Biologiese interaksie om siektes en plae te bestry met spesiale verwysing na natuurlike vyande.

Biosied ("Biocide") - 'n Dodende of verdelgende middel, bv. bakterisied, fungisied, fitosied, nematosied ens.

Biotipe ("Biotype") - 'n Populasie van geneties identiese indiwidue wat subspesies, serotipes en onderafdelings van fissiologiese rasse wat fisiologies onderskei kan word, insluit. 
Biotoetse ("Bioassay") - Kwantitatiewe bepaling van biologies aktiewe stowwe aan die hand van hulle inwerking op lewende organismes onder gestandaardiseerde toestande.

Biotroof ("Biotroph") - 'n Organisme wat vir sy voedselvoorsiening uitsluitend van ander lewende organismes afhanklik is.

Blaarskroei

(1) Blaarnekrose as gevolg van infeksie deur 'n patogeen ("Leaf blight").

(2) Blaarnekrose as gevolg van fitotoksisiteit of voedingsgebrek ("Leaf scorch").

Blaarvlek ("Leaf spot") - 'n Lokale min of meer ronde blaarletsel wat van die omringde weefsel in kleur verskil en dikwels nekroties is.

Blouvlek ("Blue stain") - 'n Oorwegend blou verkleuring van die splinthout by bome as gevolg van swamaantasting.

Brand ("Smut") - 'n Sickte wat deur 'n swam van die Orde Ustilaginales veroorsaak word. Dit is dikwels gekenmerk deur die vorming van roctagtige spoormassas.

Brandvlek ("Scald") - 'n Term wat vir vlekke met 'n fisiologiese oorsaak gebruik word bv. as gevolg van fel sonlig.

Blywende virus ("Persistent virus") - 'n Virus wat vir lang periodes en selfs vir sy hele leeftyd in 'n vektor behoue bly en van besmette na gesonde plante oorgedra word. Sulke virusse kan selfs na die nageslag oorgedra word en het gewoonlik 'n lang latente periode.

Chemoterapeutiese indeks ("Chemotherapeutic index") - Die verhouding van laagste dodende konsentrasie van 'n terapeutiese chemikalic tot hoogste konsentrasie wat nie fitotoksies is nie. Slegs ' $n$ indeks $<1$ bied moontlikhede vir praktiese aanwending.

Chemoterapie ("Chemotherapy") - Behandeling van siektes met chemikalieë om genesing te bewerkstellig.

Chemotrofies ("Chemotrophic") - Die verkryging van grocienergie van anorganiese voedingstowwe, sonder om gebruik tc maak van lig.

Chlorose ("Chlorosis") - Geheel of gedeeltelike afwesigheid van die normale groen kleur in plantdele as gevolg van 'n gebrek aan chlorofil.

Deflokkuleermiddel ("Deflocculent") - 'n Middel wat by 'n spuitmengsel gevoeg word om te voorkom dat die vaste deeltjies van 'n plaagbcheermiddel saampak of neerslaan.

Differensiaalvoedsterplant ("Differential host")

(1) 'n Voedsterplant wat op besmetting sodanig reageer dat dit tussen isolate van spesifieke rasse van 'n patogeen kan onderskei.

(2) 'n plant wat 'n kenmerkende reaksie vir 'n bepaalde virus gee waardeur dit van ander aanwesige virusse onderskei kan word.

Donsskimmel ("Downy mildew") - 'n Siekteverskynsel wat gewoonlik op die oppervlak van plante sigbaar is as 'n donsige wit groeisel, veroorsaak deur 'n parasitiese fungus van die Perenosporaceae.

Dosis ("Dosage") - (1) Die hoeveelheid swamdoder ens. wat per eenheidsoppervlakte, volume of massa toegedien word. (2) Die hoeveelheid van 'n patogeen inokulum wat gebruik word om lewende voedsterplante te inokuleer, veral in kwantitatiewe effekstudies.
Dosisresponsiekurwe ("Dosage-response curve") - 'n Kurwe wat geteken word deur die dosis of konsentrasie van 'n bestrydingsmiddel te karteer teen die mate van onderdrukking van miseliumgroei of die ontkieming van spore of konidiums in 'n laboratoriumtoets.

Draer ("Carrier") - 'n Organisme wat 'n patogeen huisves sonder om siektetekens te wys.

Draagstof ("Carrier") - 'n Onaktiewe vloeistof of vastestof in pociervorm wat as verdunningsmiddel vir die aktiewe bestanddeel van 'n swamdoder dien, bv. water of kaolien.

Druppelspektrum ("Drop spectrum") - Die indeling van 'n spuitnewel in klasintervalle volgens getal en/of groottes van die druppels.

Effektiewe inokulumdosis ("Effective inoculum dose") - Die hoeveelheid inokulum wat nodig is om suksesvolle besmetting van 'n voedsterplant te bewerkstellig. Veral in geval van bakteriesiektes is dikwels veelvoudige besmettingseenhede nodig vir 'n suksesvolle inokulasie.

Ektotrofies ("Ectotrophic") - Die oppervlakkige groei van 'n patogeen waarby die kolonisasie van weefsel nie dieper as die epidermale selle plaasvind nie soos in die geval van meeldouswamme.

Emulgeerbare konsentraat ("Emulsifiable concentrate") - 'n Helder vloeistof (watermengbare olietipe) waarin 'n beheermiddel opgelos is en wat 'n emulsie vorm wanneer dit met water gemeng word.

Emulgeermiddel ("Emulsifier") - 'n Middel wat die dispersie van een vloeistof in ' $n$ ander verhoog of stabiliseer.

Emulsie ("Emulsion") - Mengsel van twee nie in mekaar oplosbare vloeistowwe waarvan die een in baie klein druppels verdecl is.

Enkelgeenweerstand ("Monogenic resistance") - Weerstandbiedendheid wat deur 'n enkel geenpaar beheer word.

Enkelvoudigerentesiekte ("Simple interest disease") - 'n Sickte wat in een seisoen vanaf 'n konstante besmettingsbron ontwikkel soos by Fusarium-verlepsiekte van aartappels en waar die siekte vorder volgens die formule log 1/1-x waarin $\mathrm{x}$ die siek deel van die populasie voorstel (term geskep deur J.E. van der Plank in "Plant Diseases: epidemics and control" Academic Press, 1963).

Epidemie ("Epidemic") - 'n Wydverspreide tydelike sterk toename in die omvang van 'n besmetlike siekte. Waar die term epidemie aanleiding kan gee tot verwarring met 'n dierlike epidemie, word die term plantsiekte-epidemie ("epiphytotic") gebruik.

Epidemiologie ("Epidemiology") - Die wetenskap van die faktore wat die ontstaan en verspreiding van besmetlike siektes beinvloed.

Epifiet ("Epiphyte") - Mikro-organismes wat op plantoppervlaktes leef in 'n nieparasitiese verhouding.

Epinastie ("Epinasty") - Die ombuiging van 'n blaarstingel na onder toe sonder verlies van turgor, sodat ' $n$ stomphoek tussen stingel en blaarstingel ontstaan.

Enasie ("Enation") - 'n Abnormale uitgroeisel van die oppervlakte van 'n orgaan soos stam of blaar.

Etiologie ("Aetiology") - Die wetenskap van die oorsake van plantsiektes. Dit sluit in die identifikasie van die oorsaaklike faktore, studie van die opeenvolging van gebeurtenisse wat tot die verskyning van siektesimptome lei en die faktore wat ontwikkeling van die siekte beïnvloed. 
Fakultatiewe parasiet ("Facultative parasite") - Parasiet wat onder natuurlike toestande ook as saprofiet kan leef en op 'n kunsmatige voedingsmedium gekweek kan word.

Fassiasie ("Fasciation") - Die vermenigvuldiging van 'n loot sonder dat die elemente heeltemal skei wat dit die voorkoms van 'n afgeplatte bondel saamgegroeide lote gee.

Fillodie ("Phyllody") - Die vervanging van blomdele deur blaarvormige strukture.

Fillovlak ("Phylloplane") - Die mikrohabitat van die blaaroppervlak.

Fisiologiese ras ("Physiologic race") - 'n Parasitiese taxon wat gekenmerk word deur spesialisasie ten opsigte van verskillende kultivars van 'n enkele voedsterplant spesies.

Fisiologiese siekte ("Disorder") - 'n Skielike afwyking van die normale funksionering van fisiologiese prosesse wat uit ander oorsake as patogene organismes en virusse voortspruit bv. mineraaltekort, genetiese afwykings, laetemperatuurbeskadinging, ens.

Fitiatrie ("Phytiatry") - Die bestryding van plantsiektes. Fitoaleksien ("Phytoalexin") - 'n Stof wat in 'n hoër plant as gevolg van 'n genetiese, fisiese of biologiese stimulus gevorm kan word en wat die groei van sekere mikroorganismes kan verhinder.

Fitopatogeen ("Phytopathogen") - 'n Organisme of virus wat 'n siekte in plante kan veroorsaak.

Fitosanitasie ("Phytosanitation") - Die verwydering of vernietiging van besmette plantmateriaal of enige ander maatreël wat herbesmetting met 'n plantsiekte kan voorkom.

Fitotoksemia ("Phytotoxemia") - Sien Toksikose.

Fitotoksisiteit ("Phytotoxicity") - Beskadigende werking ten opsigte van plante of plantegroei.

Flodderbehandeling ("Slurry treatment") - Saadbehandeling met ' $n$ halfvloeibare mengsel van soliede deeltjies in 'n vloeistof, gewoonlik water.

Forma (afgekort: f; meervoud: formae) - 'n Onderafdeling van 'n spesie wat op 'n baie beperkte aantal morfologiese kenmerke gebaseer is (International Code of Botanical Nomenclature, Art. 4).

Forma specialis (afgekort: f.sp.; meervoud: formae speciales) - 'n Parasitiese taxon wat binne die grense van 'n spesie nie morfologies nie, maar slegs fisiologies deur aanpassing aan een of meer voedsterplante uitgeken kan word.

Formulasie ("Formulation") - 'n Opgawe van die geaardheid en hoeveelheid van die bestanddele van 'n siektebestrydingsmiddel.

Fungisied ("Fungicide") - Sien Swamdoder.

Fungistase ("Fungistasis") - 'n Omkeerbare groeibelemmering van 'n swam; groei word hervat sodra die remstof verwyder of verdun word.

Fungistatiese middel ("Fungistat") - 'n Substansie wat die groei van 'n swam verhinder sonder om dit dood te maak.

Fungus ("Fungus") - 'n Organisme wat swamdrade of hifes vorm en wat reproduseer deur middel van spore wat sowel geslagtelik as ongeslagtelik gevorm kan word.

Fynsproei ("Atomize") - Die toediening van 'n vloeistof in fyn verdeelde druppeltjies deur middel van 'n fynsproeier.
Fynsproeier ("Atomizer") - 'n Toestel waarmee 'n vloeistof onder druk deur 'n gepaste mondstuk in fyn druppeltjies verdeel word.

Gal ("Gall") - 'n Lokale opswelling of uitgroeisel van 'n plantweefsel wat gewoonlik 'n karakteristieke vorm het en wat as gevolg van die aksie van 'n patogeen of ander organisme ontstaan.

Gebreksiekte ("Deficiency disease") - 'n Fisiologiese siekte wat veroorsaak word deur 'n mineraaltekort.

Geen-vir-geen begrip ("Gene-for-gene concept") - Die begrip dat korresponderende gene vir bestandheid en virulensie respektiewelik in voedsterplant en patogeen bestaan.

Geïnduseerde weerstand ("Induced resistance") - Nieerflike weerstand wat deur en of ander predisponerende behandeling verleen word.

Geïntegreerde beheer ("Integrated control") - Die komplementêre gebruik van biologiese en chemiese metodes vir die bestryding van patogene.

Gemaskeerde virus (“Masked virus") - 'n Virus wat in 'n plant aanwesig is sonder om sicktesimptome te veroorsaak.

Gesertifiseerde gewas (“Certified crop") - Gewas waarvan die plante tipe-eg is en waarvan die voorkoms van bepaalde siektes nie gespesifiseerde toleransiegrense oorskry nie.

Geswel ("Tumour") - 'n Misvorming of opswelling van voedsterplantdele as gevolg van lokale groei en vergroting van weefselselle. Sien ook gal waarby die nadruk op die verwekker val.

Gomsiekte ("Gummosis") - Simptome van 'n gummose.

Gnotobiotiese groei ("Gnotobiotic growth") - Die groei van 'n organisme in die afwesigheid van ander organismes soos in reinkulture van mikro-organismes

Groei-inhibeerder ("Growth inhibitor") - Middel wat die groei van 'n organisme verhinder. Indien die inhibeerder toksies is, kan hoë konsentrasies die groei onomkeerbaar belet, terwyl dit by lae konsentrasies moontlik omkeerbaar is deur dit in 'n inhibeerdervrye omgewing terug te bring en dan as 'n groeivertragingsmiddel fungeer.

Groeivert ragingsmiddel ("Growth retardant") - 'n Middel wat die groeitempo van 'n organisme verminder.

Grondontsmettingsmiddel ("Soil disinfectant") - 'n Middel in poeier, vloeistof of gasvorm wat aan die grond toegedien word om patogene organismes in die onmiddelike omgewing van groeiende of verwagte wortelstelsels dood te maak.

Grondsterilisasie ("Soil sterilazation") - Die behandeling van grond met 'n toksiese middel in gas of vloeistofvorm of deur hitte om dit van alle lewende organismes te bevry.

Gummose ("Gummosis") - Die uitskeiding van gom deur 'n weefsel of 'n orgaan wat uitwendig as "gomsiekte"simptoom kenbaar is, of ' $n$ inwendige opstopping van die vaatbundels as gevolg van infeksie met 'n vaatpatogeen.

Habitat ("Habitat") - Die natuurlike groeiplek van 'n organisme.

Haelgat ("Shot hole") - 'n Siektesimptoom op blare gekenmerk deur nekrotiese letsels wat uit die blaarskyf val en ronde gaatjies agterlaat. Dit kan 'n fisiologiese of patologiese oorsaak hê. 
Halfblaartoets ("Half-leaf test") - Blaarhelftes is die gewone toetseenheid vir kwantitatiewe bepaling van besmettingsvermoë van 'n bakterie- of virussuspensie in geïnokulecrde blare, aangesien daar minder verskil tussen blaarhelftes as tussen blare voorkom.

Handlangervirus ("Helper virus") - 'n Virus wat deur sy vektor slegs in die aanwesigheid van 'n tweede virus oorgedra word.

Heksebesem ("Witches broom") - 'n Abnormale plaaslike ophoping van takke of lote as gevolg van 'n te vroeë en oordadige uitloop van knoppe. Hierdie besondere tipe van misvorming kan die gevolg van infeksie wees.

Hervestigingsiekte ("Replant disease") - 'n Ernstige afname in die tempo van wortel-en lootgroei van 'n tweede aanplanting van 'n meerjarige gewas op dieselfde plek waar bome van dieselfde of ' $n$ naverwante plantspesie gestaan het en wat deur 'n patogeen veroorsaak word.

Heteresies ("Heteroecious") - 'n Patogeen of 'n plaag wat sy lewenskring op twee verskillende voedsterplante voltooi.

Heterotroof ("Heterotroph") - 'n Organisme wat organiese stowwe wat deur ander oganismes geproduseer word, as voedsel benut.

Hiperparasiet ("Hyperparasite") - Parasiet van 'n ander parasiet of patogeen.

Hiperplasie ("Hyperplasia") - Vergroting van 'n weefsel as gevolg van oormatige seldeling.

Hipersensitiwiteit ("Hypersensitivity") - Die hewige reaksie van 'n plant teen aantasting deur 'n patogeen of virus wat die onmiddellike dood van die aangevalle weefsel veroorsaak om aldus die verdere verspreiding van besmetting te voorkom.

Hipertrofie ("Hypertrophy") - Abnormale groei van weefsels of organe as gevolg van die abnormale vergroting van selle.

Hipoplasie ("Hypoplasia") - Onderontwikkeling van 'n weefsel of orgaan as gevolg van verminderde seldeling wat deur 'n patogeen of inhiberende stowwe veroorsaak word.

Hitteterapie ("Thermotherapy") - Genesing deur middel van warmte.

Horisontale weerstand ("Horizontal resistance") - Weerstand wat gelykweg teen alle fisiologies rasse van 'n patogeen werk. Die term is ekwiwalent met nierasspesifieke weerstand.

Houstorium ("Haustorium") - 'n Intrasellulêre struktuur wat deur die interaksie van 'n swamhife in die voedsterplantsel waarin dit binnedring, gevorm is en wat die fungus in staat stel om voedingstowwe uit die sel te absorbeer sonder om dit te vernietig.

Immuniteit ("Immunity") - Die ontbreek van eienskappe wat 'n organisme geskik maak of die aanwesigheid van eienskappe wat die organisme ongeskik maak as voedsterplant vir parasitisme deur 'n patogeen of virus.

Indeksering ("Indexing") - Enige prosedure om die aanwesigheid van bekende virusse in vatbare plante aan te toon.

Indikatorplant ("Indicator plant") - 'n Plant wat op kenmerkende manier op 'n bepaalde patogeen of omgewingsfaktor reageer en derhalwe gebruik word om die aanwesigheid van die patogeen of omgewingsfaktor aan te toon.
Infeksie ("Infection") - Die vestiging van 'n patogeen in 'n voedsterplant na penetrasie.

Infeksielokus ("Infection court") - Die plek van 'n voedsterplant waar 'n patogeen of virus binnedring.

Infeksiepen ("Infection peg") - 'n Struktuur wat om 'n hife vorm wanneer dit die wand van 'n lewende gasheersel binnedring en wat uit houtstof, sellulose of suberien ens. opgebou is.

Infekteer ("Infect") - 'n Handeling om 'n tydelike of blywende parasitiese verwantskap tussen 'n patogeen of virus en voedsterplant daar te stel.

Infektief ("Infective") - Die vermoë van 'n organisme of ' $n$ virus om infeksie te veroorsaak en geld behalwe vir 'n patogeen ook vir 'n vektor wat die patogeen uit- of inwendig kan dra.

Infiltrasie ("Infiltration") - Die invoering van 'n vloeistof of inokulum onder druk bv. deur 'n voorafgaande vakuum.

Inheemse siekte ("Endemic disease") - 'n Siekte wat reëlmatig in 'n bepaalde gebied soos 'n land of deel daarvan voorkom en daartoe beperk is.

Inokulasie ("Inoculation") - Die handeling van inokuleer Inokuleer ("Inoculate") - Die oordrag van inokulum na ' $n$ voedsterplant of in ' $n$ voedingsmedium met die doel om infeksie teweeg te bring.

Inokulum ("Inoculum") - Materiaal wat vir inokulasie aangewend word en wat virusdeeltjies of mikro-organismes bevat.

Inspuiting ("Injection") - Die introduksie van 'n vloeistof of 'n inokulum deur middel van 'n onderhuidse spuitnaald.

Intersellulêr ("Intercellular") - Tussen die selle.

Intrasellulêr ("Intracellular") - Binne die selle.

Inwendige (interne) terapie ("Internal therapy") - Siektebestryding deur middel van sistemiese middels of sistemiese swamdoders.

Isolaat ("Isolate") - 'n Reinkultuur van 'n organisme wat van 'n voedsterplant of substraat afgesonder is. Sien ook virusisolaat.

Isolasie ("Isolation") -

(I) Die isoleer van 'n mikro-organisme of virus van 'n substraat of voedsterplant.

(2) Die instandhouding van gesonde plantmateriaal op plekke wat ver van bronne van inokulum verwyder is of in spesiale afskortings gehou word.

Isoleer ("Isolate") - Die proses van afsondering van 'n organisme vanaf ' $n$ voedsterplant of substraat en die in reinkultuur bring daarvan.

Kallus ("Callus") - Parenchiemweefsel van kambiale oorsprong wat as gevolg van verwonding of infeksie deur ' $n$ patogeen ontwikkel.

Kanker ("Canker") - 'n Ingevalle nekrotiese letsel van wortels, stingels of takke waaronder die weefsel tot op die xileem kan verweer en wat by houtagtige plante in sy uitbreiding dikwels beperk word deur omringing met 'n wondkallus wat egter in teenstelling tot basnekrose nie in staat is om die infeksie te stuit nie.

Kleefmiddel (“Adhesive, Sticker”) - 'n Stof wat by 'n beheermiddel gevoeg word om sy vasklewing op 'n gegewe oppervlak te verhoog.

Kleefvermoë ("Tenacity") - Die vermoë van 'n neerslag van 'n bestrydingsmiddel om verwydering as gevolg van verwering of ander fisiese inwerking te weerstaan. 
Kleinblaar (“Little leaf') - 'n Siektesimptoom by vrugtebome waarby sommige blare abnormaal klein bly as gevolg van 'n niepatogene oorsaak soos sinkgebrek by perskes.

Klendusiteit ("Klendusity") - Die vermoë van 'n vatbare kultivar om 'n besmetting te ontsnap as gevolg van die besit van 'n eienskap wat suksesvolle inokulasie verhinder of belemmer onder toestande wat bevorderlik is vir besmetting van ander vatbare kultivars.

Kloon ("Clone") - 'n Geneties eenvormige groep van organismes wat oorspronklik deur vegetatiewe vermeerdering van een enkele indiwidu afkomstig is.

Koch se postulate ("Koch's postulates") - Die voorskrifte waaraan 'n mikro-organisme moet voldoen om as 'n patogeen beskou te word. Dit sluit in:

(1) Gereelde assosiasie van die veronderstelde patogeen met dieselfde siektesimptome.

(2) Die organisme moet in reinkultuur gebring word weg van die gasheerplant.

(3) Dit moet in 'n gesonde plant herinokuleer word.

(4) Simptome moet dan ontwikkel wat identies is aan dié van die oorspronklike siekteverskynsel.

(5) Die oorsaaklike organisme moet dan van die toetsplant herisoleer word en identies wees met die oorspronk like geïsoleerde organisme.

Kodenaam ("Coined name") - Is die algemeen internasionaal aanvaarde gebruiksnaam vir die aktiewe bestanddeel van 'n beheermiddel.

Kolonie ("Colony") - 'n Kolleksie van indiwidue (Bakterieë, giste ens.) wat saam vermeerder of hifes wat uitgroei en 'n kloon kan vorm indien dit van een spoor of sel ontwikkel.

Kommensalisme ("Commensalism”) - Die saamleef van twee ongelyksoortige organismes waarvan die een voordeel trek sonder om die ander te benadeel of te bevoordeel.

Kompleks ("Complex") - 'n Kollektiewe term vir alle lyne van 'n virus of van 'n swamspesie.

Komplekse siekte ("Composite disease") - Siekte wat deur twee of meer patogene organismes of virusse veroorsaak word en waarvan die simptome nie herkenbaar is om aan een van die patogene afsonderlik te behoort nie.

Konsentraatbespuiting ("Concentrate spraying") - Die toediening van 'n onverdunde of gering verdunde formulasie van ' $n$ bestrydingsmiddel.

Kontaminant ("Contaminant") - 'n Ongewenste stof, mikro-organisme of virus wat toevallig in 'n kultuur, substraat of voedingsbodem beland het.

Kontrole ("Control, check") - Onbehandelde proefvoorwerpe, of dié wat 'n standaard behandeling gegee is om dit met eksperimentele behandelings te vergelyk.

Kringvlek ("Ring spot") - 'n Vlek (gewoonlik blaarvlek) wat deur 'n kring omring word wat kloroties of nekroties is, of uit abnormaal donkergroen weefsel bestaan.

Kriptogram ("Cryptogram") - 'n Beskrywende kode wat die belangrikste eienskappe van 'n virus opsom en uit vier pare simbole bestaan.

Kroesblaar = Krulblaar ("Leaf curl”) - Gegolfde vervorming van blare as gevolg van ongelyke groei van blaarweefsels.

Kruisbeskerming ("Cross protection") - Die wederkerige beskerming wat besmetting met 'n isolaat verleen teen besmetting met 'n ander isolaat of lyn.
Kultuur ("Culture") - 'n Algemene term vir 'n groeiende mikro-organisme in vitro of in vivo.

Kwarantyn ("Quarantine") - Alle handelinge wat geassosieer is met die voorkoming van verspreiding van ongewenste organismes binne en tussen landstreke.

Latente infeksie ("Latent infection") - Infeksie waarby die voedsterplant geen sigbare siektesimptome opwys nie.

Latente periode ("Latent period") -

(1) die tydperk tussen inokulasie of infeksie van 'n plant en die verskyning van siektetekens.

(2) die tydsverloop tussen faagbesmetting en die begin van lise by bakteriese selle.

(3) die periode tussen die tydstip van opname van 'n virus deur 'n vektor voor dit infektief word.

Letsel ("Lesion") - 'n Min of meer duidelike begrensde area van siek of beskadigde weefsel.

Lignituber ("Lignituber") - 'n Uitgroeisel van die gasheerselwand wat deur ' $n$ indringende swamhife geïnduseer is en wat dit omhul en blykbaar uit houtstof bestaan.

Lise ("Lysis") - Ontbinding van 'n faagbesmette bakterie, of enige ander selle van plant of dier as gevolg van enige oorsaak, patogenies of andersins.

Lokale letsel ("Primary lesion") - Word in plantvirologie gebruik vir letsels wat in geïnokuleerde blare by die plek van besmetting ontwikkel.

Lokale simptome ("Local symptoms") - Simptome wat verskyn op die plek waar 'n patogeen op of in 'n plant geplaas is

Lyn ("Strain") - 'n Virusisolaat of onderafdeling van 'n fungusspesie of -ras.

Masereer ("Macerate") - 1. Fynmaak van weefsel deur fisiese aksie. 2. Sagmaak van weefsel en losmaak van selle deur aanwending van hidrolitiese of ensiematiese middels.

Maskering ("Masking") - Die verdwyning van simptome as gevolg van veranderde omstandighede.

Massamediaandeursnit (MMD) ("Mass median diameter" (MMD)) - Die getal wat verkry word deur 'n spuitvolume in twee gelyke dele te verdeel, waarvan die een deel bestaan uit druppels met 'n deursnit kleiner as MMD en die ander helfte druppels met 'n groter diameter.

Mediaaneffektiewekonsentrasie (EK 50) ("Median effective concentration" (EK 50)) - Die konsentrasie van 'n materiaal wat nodig is om ' $n$ bepaalde effek in $50 \%$ van die indiwidue in 'n populasie van organismes teweeg te bring.

Mediaanlatenteperiode (LP 50) ("Median latent period" (LP 50)) - Die tyd wat $50 \%$ van 'n populasie van virusdraende vektors nodig het om hulle latente periode te voltooi.

Mediaanletaledosis (LD 50) ("Median lethal dose" (LD 50)) - Die dosis van 'n stof wat nodig is om $50 \%$ van die indiwidue van 'n populasie van organismes dood te maak.

Meeldou ("Powdery mildew") - 'n Oppervlakkige wit of gelerig parasitiese swamgroeisel wat deur Erysiphaceae veroorsaak word.

Meganiese oordrag ("Mechanical transmission") Oordrag van 'n patogeen van in besmette gasheerplant na $n$ gesonde een deur fisiese kontak, natuurlik of eksperimenteel en nie deur tussenkoms van in vektor nie. 
Mengbaar ("Compatible") - Wanneer verskillende behecrmiddels gemeng kan word sonder om fisiese of chemiese wisselwerking teweeg te bring wat sal lei tot vermindering in biologiese doeltreffendheid of 'n verhoging in fitotoksisiteit meebring.

Meristeempunt ("Meristem tip") - Die gebruiklike groeipunt eenheid $(0, \mathrm{I}-0,5 \mathrm{~mm}$ lank $)$ bestaande uit dic meristeem weefsel en die paar blaarprimordiums wat uitgesny word vir aseptiese groei in 'n steriele voedingsmedium met die doel om virusvrye plante te kweek.

Mikoplasma ("Mycoplasma") - 'n Uiters klein vrylewende mikro-organisme wat deur 'n membraan omhul is, maar in teenstelling met bakterië geen selwand het nie en derhalwe baic pleomorfies is.

Mikorisa ("Mycorrhiza") - 'n Swam wat in simbiose met die wortels van 'n plant leef.

Mikose ("Mycosis") - 'n Siekte of besmetting wat deur 'n parasitiese swam veroorsaak is.

Mikotrofies ("Mycotrophic") - Plante wat in simbiose met mikorisa leef.

Minimale afgiftetermyn ("Inoculation threshold period") - Die minimum tydperk wat 'n vektor nodig het om op 'n onbesmette plant te voed om siekte-oordraging te verseker.

Minimale verwerwingstermyn ("Acquisation threshold period") - Die minimum tyd wat 'n vektor nodig het om op 'n virusbron te vertoef om 'n infektiewe hoeveelheid virus te bekom.

Misvorming ("Malformation") - Afwyking van die normale vorm van 'n plantdeel of die hele plant.

Mosaïek ("Mosaic") - 'n Blaarsimptoom waarby talryke klein, verkleurde oppervlaktes ontstaan teenoor 'n agter grond van verskillende kleur (tint) en wat geneig is om duidelik begrens te wees.

Mummifikasie ("Mummification") - Die verskrompeling van normale vrugte as gevolg van besmetting met dic een of ander siekte.

Natuurlike immuniteit (“Natural immunity") - Onvatbaarheid as gevolg van oorerflike eienskappe wat immuniteit verseker.

Nawerking ("Persistence") - Die eienskap van 'n siektebestrydingsmiddel om na toediening chemiese afbreking te weerstaan.

Neerslag ("Deposit") - Die hoeveelheid en patroon van 'n spuitmiddel of stuifpoeier wat per eenheidsoppervlak van 'n plantgedeelte of enige ander oppervlak toegedien word.

Nekrofiet ("Necrophyte") - Sien Saprofiet.

Nekrose ("Necrosis") - Sterfte van 'n gewoonlik duidelik omlynde deel van 'n plant of deel van 'n weefsel.

Nekroties ("Necrotic") - Afsterwend.

Nekrotroof ("Necrotroph") - 'n Organisme wat weefsels waardeur dit groei, doodmaak om sodoende altyd 'n dooie substraat te koloniseer.

Newelbespuiting ("Mist spraying") - 'n Metode van toediening waarby 'n gekonsentreerde spuitvloeistof in 'n hoëspoedlugstroom opgebreek word tot druppels van 50-100 $\mu \mathrm{m}$ massamediaandeursnit en waarby die lug as verdunningsmiddel en draer dien.

Nosologie ("Nosology") - Die klassifisering van siektes. Oligogene weerstand ("Oligogenic resistance") - Weerstand wat deur 'n geringe aantal gene beheer word.
Omdop van saailinge ("Damping-off") - Die ineenstorting of omval van saailinge as gevolg van die ontwikkeling van 'n letsel op grondvlak. Die verskynsel is ook bekend as verdwynsiekte en omvalsiekte.

Onaktiewe stof ("Inert material") - Stof sonder biosiede aksie.

Ondersteunde virusoordraging ("Dependent virus transmission") - Die oordraging van 'n virus deur 'n vektor slegs in die aanwesigheid van 'n tweede sg. handlangervirus

Ongevoelig ("Insensitive") - Vatbaar sonder om siektesimptome te wys: uiterste vorm van verdraagsaam.

Ontkiemingsinhibeerder ("Germination inhibitor") - 'n Natuurlike of sintetiese stof wat in staat is om die ontkieming van 'n saad, of 'n infeksie-eenheid soos 'n swamspoor te belet.

Ontsmettingsmiddel ("Disinfenctant") - 'n Middel wat organismes doodmaak op die oppervlaktes van werktafels, instrumente en plantdele, asook in grond.

Onvatbaar, immuun ("Immune") - Gevrywaar teen infeksie.

Onverenigbaar ("Incompatible" Iplants]) - 'n Verhouding tussen onderstok en entloot waarby geen funksionele vereniging tussen hierdie twee plaasvind nie.

Onvermengbaar ("Incompatible" [fungicides]) - Swamdoders waarvan die samevoeging 'n ongewensde uitwerking het.

Oordragdrumpelperiode ("Transmission threshold period") - Die minimum tydperk wat 'n vektor nodig het om 'n virus oor te dra vanaf die begin van die verwerwingsvoedingstyd tot aan die einde van 'n suksesvolle toetsvoeding.

Oortreksels ("Mould covers") - Dit sluit alle sigbare miseliumswamgroei op plantdele soos blare, stingels en vrugte in. Sien ook meeldou en roetskimmel.

Outoësies ("Autoecious") - 'n Patogeen (of plaag) wat sy lewenskring op een voedsterplantsoort voltooi.

Outotroof ("Autotroph") - 'n Organisme wat anorganiese stowwe as voedsel benut.

Parasiet ("Parasite") - Organisme of virus wat tydelik of permanent in nouc gemeenskap met 'n lewende organisme leef en waarvan dit sy voedsel geheel of gedeeltelik onttrek.

Passiewe weerstand ("Axeny") - 'n Weerstand wat geen afweerreaksie van die voedsterplant as gevolg van die aanwesigheid van 'n patogeen meebring nie.

Patogeen ("Pathogen") - 'n Organisme of virus wat 'n siekte in 'n gasorganisme kan veroorsaak.

Patogenisiteit ("Pathogenicity") - Die vermoë van 'n patogeen om 'n gasorganisme siek te maak en is kenmerkend vir ' $n$ bepaalde spesie, genus of ander groepering. Vir indiwiduele patogenisiteit sien Virulensie.

Patotipe ("Pathotype") - 'n Populasie van 'n patogeen waarvan alle indiwidue bepaalde patogene eienskappe gemeen het, veral ten opsigte van 'n voedsterplantreeks.

Patotoksien ("Pathotoxin") - 'n Toksien wat deur 'n patogeen geproduseer word en in staat is om siektesimptome te veroorsaak

Penetrasie ("Penetration”) - Aanvanklike binnedringing van 'n voedsterplant deur 'n patogeen.

Pertofiet ("Perthophyte") - Plantaardige organisme wat 
voedsel onttrek aan dooie weefsel van 'n lewende gasheerplant.

Plantpatologie ("Plant Pathology") - Die wetenskap van siektes in plante. Dit is sinoniem met plantsiektekunde en fitopatologie, maar word in Suid-Afrika verkieslik gebruik.

Poligeniese weerstand ("Polygenic resistance") - Bestandheid wat deur 'n aantal gene beheer word.

Pre-immuniteit ("Premunity") - 'n Verworwe niespesifieke immuniteit wat plante vertoon nadat hulle met 'n organisme behandel is wat die plant teen infeksie met 'n verwante patogeen beskerm.

Proliferasie ("Proliferation") - Ongeremde hiperplasie soos in die geval van 'n geswel of heksebesem.

Puisie ("Pustule") - 'n Blaasagtige letsel op blaar, stingel of vrug waarop die vrugdraende struktuur van 'n swam uitbreek.

Ras ("Race") - Sien fisiologiese ras.

Reinkultuur ("Pure culture") - Isolaat of enkelspoorkultuur van 'n organisme wat in die afwesigheid van ander organismes groei.

Residu ("Residue") - Die hoeveelheid spuitstof, stuifmiddel of aktiewe afbreekprodukte daarvan wat op 'n sekere tydstip na toediening in of op 'n plant of gedeelte daarvan aanwesig is. Dit word gewoonlik as $\mu \mathrm{g} / \mathrm{g}$ of dpm (dele per miljoen) per eenheidsmassa van die plant uitgedruk.

Retensieperiode ("Retension period") - Die tydperk waartydens 'n vektor na die verwerwingsvoedingstyd in staat is om 'n virus oor te dra.

Risomorf ("Rhizomorph") - 'n Struktuur wat uit baie hifes bestaan waarvan die buitenstes verdikte en gepigmenteerde selwande het en 'n weerstandbiedende skil vorm, terwyl die inwendige hifes in 'n hoogs doeltreffende vervoerstelsel gedifferensieer is.

Risosfeer ("Rhizosphere") -Die mikrohabitat rondom en beïnvloed deur wortels.

Roes ("Rust") - 'n Siekte wat veroorsaak word deur 'n swam van die orde Uredinales. Dit word dikwels gekenmerk deur die vorming van roeskleurige puisies op blare en stingels.

Roetskimmel ("Sooty mould") - Swart nieparasitiese swamgroei wat deur Capnodiaceae veroorsaak word.

Rolblaar ("Leaf roll") - Ombuiging van die blaarrand na die middelnerf toe.

Rosetvorming ("Rosetting") - Aansienlike vermindering in stingellitgroei in die vertikale as, sonder vergelykbare vermindering in die grootte van blare.

Saadbehandeling ("Seed treatment") - Die proses om sade met 'n swamdoder ens. te omhul of daarin te drenk.

Saailingweerstand ("Seedling resistance") - Weerstand teen siekte wat reeds in die saailingstadium manifesteer.

Saamgestelderentesiekte ("Compound interest disease") - 'n Siekte waarby die inokulum in een seisoen in opvolgende generasies van besmetting toeneem en die siekte vorder volgens die formule, $\log . \mathrm{x} / \mathrm{l}-\mathrm{x}$ waarin $\mathrm{x}$ die siek deel van die populasie voorstel (term geskep deur J.E. van der Plank in "Plant Diseases: epidemics and control" Academic Press, 1963)

Saprofiet ("Saprophyte") - Plantaardige organisme of swam wat van dooie organiese materiaal leef.

Satellietvirus ("Satellite virus") - 'n Virus wat slegs ver- meerder in die aanwesigheid van 'n spesifieke tweede virus.

Semiblywende virus ("Semi-persistent virus") - 'n Virus wat vir hoogstens enkele dae deur vektore van bcsmette na gesonde plante oorgedra kan word.

Sensitief ("Sensitive") - Om met hewige simptome op die aantasting van 'n bepaalde patogeen te reageer.

Siekte ("Disease") - 'n Skadelike afwyking van die normale funksionering van fisiologiese prosesse wat deur patogene organismes of virusse veroorsaak word.

Siektebeeld ("Syndrome") - Die vir "n bepaalde siekte kenmerkende kompleks van simptome.

Siektebeheer ("Disease control") - Sien Beheer.

Siektebestryding ("Disease control") - Sien Bestryding.

Siektegraad ("Disease rating") - 'n Aanduiding van die mate van besmetting wat afhanklik van die aard van die siekte volgens 'n bepaalde formule bepaal word.

Siektegradiënt ("Disease gradiënt") - Die aanduiding van 'n verandering in die omvang van 'n siekte met toenemende afstand van 'n siektebron.

Siekte-ontsnapping ("Disease escape") - Die voorkoms van bestandheid by 'n vatbare voedsterplant onder natuurlike toestande waar patogeen en vatbare plantweefsel nie gelyktydig aanwesig is nie.

Simbiose ("Symbiosis") - Die saamleef van twee ongelyksoortige organismes tot een of albei se voordeel. Sien ook Wederkerige simbiose en Kommensalisme.

Simptoom ("Symptom") - 'n Sigbare abnormaliteit in groei as gevolg van siekte. Indien 'n siekte meer as een tipe simptoom produseer, word die eersverskynende tipe primêre simptoom genoem en die daaropvolgende tipe sekondêre simptoom.

Sinergisme ("Synergism") - Samewerking van faktore waarvan die effek groter is as die som van effekte van elke faktor afsonderlik. Die faktore kan van biotiese of abiotiese aard wees, soos organismes en bestrydingsmiddels.

Sistemiese besmetting ("Systemic infection") - Die voorkoms van 'n patogeen dwarsdeur die plant.

Sistemiese middel ("Systemic agent") - 'n Middel wat na binnedringing in die plant opbreek waarby een of meer sistemiese swamdodende komponente gevorm word.

Sistemiese simptome ("Systemic symptoms") - Siekteverskynsels (van virussiektes) wat elders as die plek van inokulasie verskyn.

Sistemiese swamdoder ("Systemic fungicide") - 'n Swamdoder wat deur die plantoppervlak geabsorbeer word en van die plek waar dit toegedien is, intern versprei.

Skaafmiddel ("Abrasive") - 'n Skuurmiddel bestaande uit fyn deeltjies van 'n materiaal soos karborundum, houtskool of soortgelyke stowwe wat voor inokulasie op blare bestuif of aan die inokulum toegevoeg word om meganiese oordrag van 'n plantvirus te vergemaklik.

Skade ("Damage") - Die ekonomies nadelige effek van 'n beskadiging of siekte.

Skeidingsplant ("Screening host") - 'n Plant waarin een of meer virusse uit 'n mengsel van ander virusse geskei kan word.

Skroei ("Scorch") - Enige simptoom wat die aksie van 'n vlam of vuur op die aangetaste plantdeel veral blare suggereer. Op 'n bepaalde voedsterplant kan skroeisimptome 'n verskeidenheid van oorsake hê 
Skurfte ("Scab”) - Oppervlakkige, gelokaliseerde growwe letsels of duike waarvan die oppervlak abnormaal kurkagtig verdik kan wees.

Spatvlek ("Blotch") - 'n Groot, verkleurde oppervlakte van 'n vrug, blaar, stingel ens. Op blare hou die omlyning van die vlek geen verband met die verloop van die are nic.

Spesialisasie ("Specialisation") - Die aanpassing van 'n patogeen aan bepaalde voedsterplante soos in die geval van 'n forma specialis.

Spesifisiteit ("Specificity") - 'n Vorm van interaksie tussen patogeen en voedsterplant. Twee soorte van interaksie word aangetref:

(a) Spesifieke interaksie of interaksie in 'n geen-vir-geensisteem.

(b) Niespesifieke interaksie of interaksie in afwesigheid van 'n geen-vir-geen-sisteem.

Spreimiddel ("Spreader") - 'n Stof wat by 'n spuitmengsel gevoeg word om die verspreiding daarvan oor 'n gegewe oppervlakte te verbeter.

Spuitapparaat ("Sprayer") - 'n Apparaat vir die toediening van 'n spuitmiddel om dit doeltreffend en egalig oor 'n oppervlakte te versprei.

Spuitmengsel ("Spray mixture") - 'n Mengsel van 'n bepaalde hoeveelheid beheermiddel met ' $n$ bepaalde volume draervloeistof. Dit kan in die vorm van suspensie (benatbare poeier), emulsie (emulsifeerbare konsentraat) of oplossing wees.

Spuitmiddel ("Spray material") - Enige chemikalie met spesifieke eienskappe wat gebruik kan word vir die bestryding van siektes, plae of onkruide en wat in vloeibare vorm toegedien word.

Spuitvloeistof ("Spray liquid") - 'n Spuitmengsel wat vir aanwending gereedgemaak is.

Stigmonose ("Stigmonosis") - 'n Toksikose wat deur suiginsekte veroorsaak word.

Stuifmengsel ("Dust mixture”) - 'n Mengsel van twee of meer stuifpociers om 'n wyer reeks van siektes te beheer.

Stuifpoeier ("Dust") - 'n Bestrydingsmiddel wat in poeiervorm geformuleer is en in hierdie vorm aangewend word.

Substraat ("Substratum") - Dooie of lewende materiaal waarop of waarin 'n organisme groei.

Suspensie ("Suspension") - 'n Vloeistof waarin onoplosbare vaste deeltjies in fynverdeelde toestand voorkom en wat na verloop van tyd besink.

Swam ("Fungus") - Sien Fungus.

Swamdoder ("Fungicide") - 'n Middel wat swamspore of miselium doodmaak.

Swamonkruiddoder ("Mycoherbicide") - Plantpatogene swam wat vir die biologiese beheer van onkruide aangewend word.

Swamsiekte ("Fungus disease") - 'n Siekte of infeksie wat deur 'n fungus veroorsaak word.

Taxon ("Taxon") - Enige taksonomiese groep.

Teenskuimmiddel ("Anti-frothing agent") - 'n Middel wat gebruik word om die vorming van skuim by 'n draaiende vloeistof in die tenk van 'n spuitmasjien te voorkom.

Teratogenies ("Teratogenic") - Die eienskap om misvorming te veroorsaak.
Terugsterwing (“Dieback”) - Sterfte van 'n loot wat by die toppunt begin en na ondertoe tot by die hoofstam of -stingel vorder.

Tillevorming ("Tylosis") - Die vorming van balonvormige ingroeiings iil die lumen van ' $n$ vaatbundel.

Toediening ("Application") - Die proses van aanwending van 'n beheermiddel met behulp van 'n geskikte apparaat en volgens ' $n$ bepaalde metode.

Toksien ("Toxin") - 'n Organiese giftige stof wat deur 'n organisme geproduseer word.

Toksiese middel ("Toxicant") - Giftige stowwe wat gewoonlik toksiene uitsluit en veral gebruik word as swamdoders en bakterisiede.

Toksikose ("Toxicosis") - 'n Plantsiekte wat deur 'n insektoksien veroorsaak word.

Toksisiteit ("Toxicity") - Die mate van nadelige invloed wat deur' $n$ toksien of ' $n$ toksiese middel op die lewensprosesse van 'n organisme uitgeoefen word.

Tracheomikose ("Tracheomycosis") - 'n Vaatsiekte waarby die patogeen tot die vaatbundels van die plant beperk is en waarby in teenstelling tot 'n verwelksiekte geen verlies aan turgiditeit plaasvind nie.

Uitroeiende swamdoder ("Eradicant fungicide") - Sien Uitroeimiddel.

Uitroeiing ("Eradication") - Die eliminering van 'n patogeen of plaag van 'n voedsterplant of sy omgewing of die totale verwydering van 'n voedsterplant om 'n siekte of plaag te bestry.

Uitroeimiddel ("Eradicant") - 'n Uitroeiende, allesdodende middel wat in geval van 'n plantsiekte aangewend word om 'n siekte te bestry nadat besmetting reeds plaasgevind het.

Uitskeiding ("Exudate") - 'n Stof of 'n vloeistof wat vanuit 'n plantdeel na die oppervlak of in 'n omgewende medium diffundeer soos blaar- en worteluitskeiding, ens.

Vaatbundelverwelksiekte ("Vascular wilt disease") - 'n Verwelksiekte waarby die patogeen tot die vaatbundels van die plant beperk bly.

Vasklewing ("Adherence") - Die vermoë van 'n plantbeskermingsmiddel of bestrydingsmiddel om aan 'n gegewe oppervlak te kan vasklou.

Vatbaarheid ("Susceptibility") - Die onderhewigheid van 'n voedsterplant aan besmetting deur patogene.

Vatbare voedsterplant ("Suscept") - 'n Plant wat onderhewig is aan 'n bepaalde siekte indien die nodige faktore vir besmetting aanwesig is.

Vektor ("Vector") - 'n Organisme (die mens uitgesluit) wat in staat is om 'n patogeen oor te dra op sodanige wyse dat besmetting plaasvind.

Veldbestandheid ("Field resistance") - Bestandheid wat onder toestande van natuurlike besmetting in die veld opgemerk word, maar nie in eksperimentele bestandheidsproewe opwys nie.

Veldimmuun ("Field immune") - Plante wat in die veld nie deur 'n patogeen aangetas word nie, hoewel dit onder kunsmatige toestande vatbaar is.

Verbeteringsmiddel (“Adjuvant”) - 'n Middel wat die chemiese of fisiese eienskappe van 'n bestrydingsmiddel verbeter of die teenliggaampieresponsie in virustoetse verhoog.

Verdraagsaam (“Tolerant") - Die vermoë van 'n plant 
om aantasting deur 'n bepaalde patogeen te verduur sonder om ernstige tekens van siekte te vertoon.

Verdunningseindpunt ("Dilution end-point") - Die stadium van verdunning van bakterieselle of viruspreparate waarby infeksie met 'n standaardmonster van die suspensie nie meer plaasvind nie.

Verdunningsmiddel (“Diluent”) - Die onaktiewe komponent van 'n spuit- of stuifmiddel wat dien om die konsentrasie van die aktiewe komponent te verminder.

Verdwerg ("Stunted") - Vermindering in die hoogte van die vertikale as wat die gevolg is van 'n progressiewe vermindering in lengte van opeenvolgende stingellitte of 'n vermindering in hul aantal.

Verdwerging ("Dwarfing") - Die opvallende kleiner bly van 'n plant in al sy afmetings, as gevolg van groeiremming.

Verdwynende virus ("Non-persistent virus") -'n Virus wat by oordrag deur 'n vektor vinnig opgeneem, maar slegs vir 'n kort periode na gesonde plante oorgedra kan word, moontlik as gevolg van die feit dat dit nie in die vektor vermeerder of sirkuleer nie.

Verdwynsiekte ('Damping-off') - Sien Omdop van saailinge.

Verenigbaar ("Compatible") - 'n Verhouding tussen onderstok en entloot waarby 'n volkome en funksionele vereniging tussen hierdie twee plaasvind. Sien ook mengbaar.

Verneweling ("Fogging") -'n Laevolume bespuiting van minder as $200 \mathrm{l}$ spuitmengsel per ha. waarby die bestrydingsmiddel in die lug bo en om die gewas in baie fyn druppels (grootte 50-150 $\mu \mathrm{m}$ ) verdeel word.

Verpilling ("Pelleting") - Die bedekking van sade met 'n onaktiewe stof of 'n swamdoder met kleefmiddel om uniforme grootte en vorm te verseker.

Verpligte parasiet ("Obligate parasite") - Parasiet wat onder natuurlike toestande slegs op 'n lewende organisme kan ontwikkel.

Verrotting ("Decay, rotting") - 'n Siekte wat gekarakteriseer is deur die ontbinding van weefsel as gevolg van die aksie van mikro-organismes.

Versagtingsmiddel ("Safener") - 'n Stof wat aan 'n spuitmengsel toegevoeg word om die fitotoksiese effek van 'n beheermiddel te verminder of moontlik te elimineer.

Verseëlmiddel ("Sealing compound") - 'n Middel wat op 'n beskadigde plantdeel aangebring word met die doel om die plant teen infeksie te beskerm.

Vertikale weerstand ("Vertical resistance") - Die weerstand wat slegs teen een of enkele rasse van 'n patogeen werk, maar nie teen alle rasse nie. Die term is ekwivalent met rasspesifieke weerstand.

Verwelksiekte ("Wilt") - 'n Siekte wat gekenmerk is deur verlies van turgiditeit en 'n oprol van blare wat deur 'n vaatbesmetting met sekere swamme of baterieë veroorsaak word. Sien ook tracheomikose.

Verwerwing ("Acquisition") - Die opname van 'n virus deur 'n vektor hetsy inwendig of deur aanklewing.

Verwerwingstoegangsperiode ("Acquisition access time") - Die tydsbestek waarin 'n toetsvektor toegang verleen word aan 'n virusbron in oordragingstoetse.

Verwerwingsvoedingstyd ("Acquisition feeding time") Die tyd wat 'n vektor op 'n virusbron moet voed om oordraging te verseker.
Verworwe immuniteit ("Acquired immunity") - Onvatbaarheid wat deur die een of ander voorbereidende be handeling wat die chemiese aktiwiteit van die plant verander, verwerf word.

Viroïed ("Viroid") - 'n Patogeen van virusagtige aard en wat slegs uit 'n ribonukleiensuur met lae molekulêre gewig bestaan.

Virulensie ("Virulence") - In algemene sin die graad van patogenisiteit van 'n parasitiese organisme of virus gemeet aan die hewigheid van siekteverskynsels in 'n voedsterplant. In die geval van differensiaalvoedsterplante beteken dit egter die aantastingspotensiaal van 'n ras van 'n patogeen wat van ander rasse verskil in die patologiese effek ten opsigte van 'n voedsterplantvariëteit.

Virus ("Virus") - 'n Nukleoproteïene wat deur bakterieweerhoudende filters gaan en in staat is om in lewende plantselle te vermeerder.

Virusdraend ("Viruliferous") - 'n Vektor wat 'n virus ronddra of dit bevat. Die vektor kan besmetlik wees of nie

Virusisolaat ("Virus isolate") - 'n Virus wat van 'n besmette plant verkry is deur inokulasie van 'n voedsterplant of deur prosedures om virusse of lyne daarvan te skei. In teenstelling tot isolate van organismes is ' $n$ virusisolaat nie noodwendig suiwer of van bekende identiteit nie.

Vlekkerigheid ("Mottle") - 'n Blaarsimptoom met talryke klein, verkleurde oppervlaktes wat nie skerp begrens is nie.

Vloeibaarheid ("Flowability") - Die vloeiende eienskap wat vloeistowwe, kolloïde en stuifpoeiers besit.

Voedingsmedium ("Culture medium") - 'n Opgemaakte substraat vir die groei van 'n mikro-organisme of ander lewende selle in vitro.

Voedsterplant ("Host plant") - 'n Lewende plant wat 'n ander organisme of virus huisves, wat vir sy bestaan daarvan afhanklik is.

Voedsterplant-patogeen-verhouding ("Host-pathogen relation") - 'n Spesifieke assosiasie en wisselwerking van 'n patogeen met 'n voedsterplant.

Voedsterplantreeks ("Host range") - Die reeks van vir patogeen of virusvatbare plantsoorte.

Volwasseplantweerstand ("Mature plant resistance") Weerstand teen patogene wat na die saailingstadium in plante opgemerk word.

Vooropkomsafsterwing ("Pre-emergence damping-off") - Afsterwing van saailinge, as gevolg van siekte, voor dat hulle bokant die oppervlak van die grond of ander groeimedium te voorskyn kom.

Vriesdroging ("Freeze-drying") - 'n Tegniek vir die preservering van mikro-organismes, waarby water onder vakuum verwyder word na vinnige bevriesing by lae temperatuur.

Wederkerige simbiose ("Mutualism") - 'n Simbiose wat tot voordeel van beide betrokke organismes is.

Weefselkultuur ("Tissue culture") - Die kunsmatige aseptiese groei van weefsels wat in die plantpatologie vernaamlik vir die groei van meristeempunte aangewend word.

Weerstand ("Resistance") - Die vermoë van 'n voedsterplant om die werking van 'n patogeen, organisme of virus, te onderdruk of te vertraag. Absolute weerstand is gelyk aan onvatbaarheid. 
Weerstandbiedend ("Resistant") - Sien Bestand.

Wisselbou ("Crop rotation") -- Die afwisseling van "n gewas met 'n onverwante gewas met die doel om patogeenpopulasies te verminder of te onderdruk.

Wisselvoedsterplant ("Alternate host") - Een van die twee voedsterplante waarop in heteresiese patogeen kan voorkom.

Wondparasiet ("Wound parasite") - 'n Parasitiese organisme wat 'n voedsterplant slegs kan aanval nadat dit eers in beskadigde weefsel gevestig is.

Wondweefsel ("Callus") - Sien Kallus

Wortelvlak ("Rhizoplane") - Die mikrohabitat van die worteloppervlak.

\section{BEDANKINGS}

Graag bedank ck prof. J.M. Kotze, Departement Mikrobiologie en Plantpatologie, Universiteit van Pretoria, en dr. B.W. Strydom, Navorsingsinstituut vir Plantbeskerming, Departement Landbou \& Watervoorsiening, vir hulle waardevolle kommentaar op my manuskrip.

\section{IITERATUURVERWYSINGS}

American Phytopathological Society (1943). Delinitions of fungicide terms, Phyopathology, 33, 624-626.

British Mycological Society (1950). Definitions of some terms used in plant pathology, Trans. Brit. Mycol. Soc., 33, 154-160.

British Mycologieal Society (1953). Some further definitions of terms used in plant pathology, Trans. Brit. Mycol. Soc., 36, 267.

Commissie voor de terminologie van de Nederlandse Planteziektenkundige Vereniging (1968). Lijst van Planteziektenkundige termen, Neth. J. Pl. Path., 74, 65-84

Commonwealth Mycological Institute (1968). Glossary of phytopathological terms, Plam Pathologist's Pocketbook. 97-106.

Marsh. R.W. 1969. Glossary of terms used in the application of crop protection measures, Sci. Hort., 21, 147-155.

Matthee, F.N. \& Thomas, A.C. (1976). Woordelys van Sleutelterme by Plantbeskerming, Decid. Fruit Grow., III-117.

Robinson, R.A. (1969). Disease resistance terminology, Rel: appl. Mycol., 48, 593-606.

Terminology Sub-committee of the Federation of British Plant Pathologists (1973). A guide to the use of terms in plant pathology, $C A B$. Phytopath. Pap., no. 17, 55 pp.

Van der Plank, J.E. (1963). Plant diseases: epidemics and control (Academic Press, New York \& London), 349 pp.

Walker, J.C. (1950). Plant Pathology. (McGraw-Hill Book Company, New York) 629 pp.

\section{ADDENDUM}

Alfabetiese lys van Engelse terme met ekwivalente Afrikaanse name/Alphabetical list of English terms with equivalent Afrikaans names.

\begin{tabular}{|c|c|c|}
\hline Abrasive & Skaafmiddel & Callus \\
\hline Acquired immunity & Verworwe immuniteit & Canker \\
\hline Acquisition & Verwerwing & Carrier \\
\hline Acquisition access time & Verwerwingstoegangsperiode & Certified crop \\
\hline Acquisition feeding time & Verwerwingswoedingstyd & Check \\
\hline Acquisition threshold period & Minimale verwerwingstermyn & Chemotherapeutic index \\
\hline Activator & Aktiveermiddel & Chemotherapy \\
\hline Active ingredient & Aktiewe bestanddeel & Chemotrophic \\
\hline Active resistance & Aktiewe weerstand & Chlorosis \\
\hline Active symptoms & Aktiewe simptome & Clone \\
\hline Adaptation & Aanpassing & Coined name \\
\hline Adherence & Vasklewing & Colony \\
\hline Adhesive & Kleefmiddel & Commensalism \\
\hline Adjuvent & Verbeteringsmiddel & Compatible \\
\hline Aerosol & Acrosol & Complex \\
\hline Aetiology & Etiologie & Composite discase \\
\hline Aggressiveness & Aggressiwitcil & Compound interest disease \\
\hline Alternate host & Wisselvoedsterplant & Concentrate spraying \\
\hline Anabiosis & Anabiose & Contuminant \\
\hline Antagonism & Antagonisme & Control \\
\hline Antagonist & Antagonis & Control agent \\
\hline Anthracnose & Antraknose & Coverage \\
\hline Antibiosis & Antibiose & Crop rotation \\
\hline Antibiotic & Antibiotikum & Cross prolection \\
\hline Anti-frothing agent & Teenskuimmiddel & Cryptogram \\
\hline Anti-fungal substance & Antimikotiese middel & Culture \\
\hline Antisporulant & Antisporulant & Culture medium \\
\hline Application & Toediening & \\
\hline Appressorium & Appressorium & Damage \\
\hline Atomize(r) & Fynsproei(er) & Damping-off \\
\hline Alrophy & Atrofic & Decay \\
\hline Altennuation & Attenuasic & Deficiency disease \\
\hline Autorecious & Outcësies & Deflocculent \\
\hline Autotroph & Outotroof & Dependent virus transmission \\
\hline Axenic culture & Akseniese kultuur & Deposit \\
\hline Axeny & Passiewe weerstand, aksenic & $\begin{array}{l}\text { Die-back } \\
\text { Differential host }\end{array}$ \\
\hline Bacteriocide & Bakteriosied & $\begin{array}{l}\text { Diluent } \\
\text { Dilution end-point }\end{array}$ \\
\hline Bacteriophage & Bakteriofaag & Disease \\
\hline Bacteriosis & Bakteriose & Disease control \\
\hline Bacterium & Bakterie & Disease escape \\
\hline Bark necrosis & Basnekrose & Discase gradient \\
\hline Bcaumont period & Beaumont-periode & Disease rating \\
\hline Bioassay & Bioloetse & Disinfectant \\
\hline Biocide & Biosied & Disorder \\
\hline Biological control & Biologiese beheer & Dosage \\
\hline Biotroph & Biotrof of & Dosage response curve \\
\hline Biotype & Biotipe & Downy mildew \\
\hline Blotch & Spatvlek & Drop spectrum \\
\hline Blue stain & Blouvlek & Dust \\
\hline
\end{tabular}

Kallus, wondweefsel
Kanker
(1) Draer, (2) Draagstof
Gesertifiseerde gewas
Kontrole
Chemoterapeutiese indeks
Chemoterapic
Chemotrofies
Chlorose
Kloon
Kodendam
Kolonic
Kommensalisme
(I) Mengbaar. (2) Verenigbaar
Kompleks
Konplekse siekte
Saamgestelderentesiekte
Konsentraatbespuiting
Kontuminant
(1) Beheer, (2) Bestryding. (3) Kontrole
Beheermiddel, Bestrydingsmiddel
Bedekking
Wisselbou
Kruisheskerming
Kriptogram
Kultuur
Vecedingsmedium
Skade
Verdwynsiekte, omdop van saailinge
Verrotting
Gebreksiekte
Defokkuleermiddel
Ondersteunde virusoordraging
Neerslag
Terugsterwing
Differensialalvoedsterplant
Verdunningsmiddel
Verdunningseindpunt
Siekte
(I) Siektebeheer, (2) Siektebestryding
Sickteontsnapping
Siektegradient
Sicktegraad
Ontsmettingsmiddel
Fisiologiese siekte
Dosis
Dosisresponsiekurwe
Donsskimmel
Druppelspektrum
Stuifpoeier

(1) Draer, (2) Draagsto
Gesertifiseerde gewas

Kontrole

Chemoterapeutiese indeks

Chemoterapic

Chemotrofies

Chlorose

Kommensalisme

Kompleks

Konplekse siekte

Saamgestelderentesiek

Kontaminant

(1) Beheer, (2) Bestryding, (3) Kontrole Beheermiddel, Beserydingsmiddel

Bedekking

Kruisheskermin

Kriptogram

Vexdingsmedium

Skide

Verdwynsiekte, omdop van saailinge

Ondersteunde virusoordraging

Neerslag

Verdunningsmiduel

Verdunningseindpun

Sickte

Sickteontsnappin

Sicktegradien

Sicklegraad

Donsskimme

Stuifpoeier 


Dust mixture
Dusting
Dwarfing

Ectotrophic

Effective inoculum dose

Emulsifiable concentrate

Emulsifier

Emulsion

Enation

Endemic disease

Epidemic

Epidemiology

Epinasty

Epiphyte

Eradicant

Eradicant fungicide

Eradication

Exudate

Facultative parasite

Fasciation

Field immune

Field resistance

Flowability

Focus of infection

Fogging

Formulation

Freeze-drying

Funigant

Fungicide

Fungistasis

Fungistat

Fungus

Fungus disease

Gall

Gene-for-gene concept

Germination inhibitor

Gnotobiotic growth

Growth inhibitor

Growth retardant

Gummosis

Habitat

Half-leaf test

Haustorium

Helper virus

Heteroecious

Heterotroph

High volume spraying

Horizontal resistance

Host pathogen relation

Host plant

Host range

Hyperparasite

Hyperplasia

Hypersensitivity

Hypertrophy

Hypoplasia

Immune
Immunity
Incitant
Incompatible
Indexing
Indicator plant
Induced resistance
Inert material
Infect
Infection
Infection court
Infection peg
Infective
Infiltration
Injection
Injury
Inoculate
Inoculation
Inoculation threshold period
Inoculum
Insensitive
Integrated control
Intercellular
Intracellutar
Internal therapy
Invasion
Isolate
Isolation

Stuifinengse

Bestuiwing

Verdwerging

Ektotrofies

Effektiewe inokulumdosis

Emulgeerbare konsentraal

Emulgecrmiddel

Emulsie

Enasie

Inheemse siekte

Epidemic

Epidemiologie

Epinastie

Epifiet

Uitroeimiddel

Uitroeiende swamdoder

Uitroeiing

Uitskeiding

Fakultatiewe parasiet

Fassiasie

Veldimmuun

Veldbestandheid

Vlocibaarheid

Besmettingsfokus

Verneweling

Formulasie

Vriesdroging

Berokingsmiddel

Swamdoder, fungisied

Fungistase

Fungistatiese middel

Fungus, Swarm

Swamsickte

Gal

Geen-vir-geen-begrip

Ontkiemingsinhibeerder

Gnotobiotiese groe

Groei-inhibeerder

Groeivertragingsmiddel

Gummose, gomsiekte

Habitat

Halfblaartoets

Houstorium

Handlangervirus

Heteresies

Heterotroof

Hoëvolumebespuiting

Horisontale weerstand

Voedsterplantpatogeenverhouding

Voedsterplant

Voedsterplantreeks

Hiperparasiet

Hiperplasie

Hipersensitiwiteit

Hipertrofie

Hipoplasie

Onvatbaar, immuun

Immuniteit

Aanjaer

l) Onverenigbaar (plante)

2) Onvermengbaar (swamdoders)

Indeksering

Indikatorplant

Geïnduscerde weerstand

Onaktiewe stof

Infekteer

Infeksie

Infeksielokus

Infeksiepen

Infektief

Infiltrasie

Inspuiting

Beskadiging

Inokuleer

Inokulasic

Minimale afgiftetermyn

Inokulum

Ongevoelig

Geintegreerde beheer

Intersellulêr

Intrasellulêr

Inwendige (interne) terapie

Binnedringing

1) Isolaat, 2) Isoleer

Isolasie
Klendusity

Koch's postulates

Latent infection

Latent period

Leaf blight

Leaf curl

Leaf ;oll

Leaf scorch

Leaf spor

Lesion

Lignituber

Little leaf

Local symptoms

Low volume spraying

Lysis

Macerate

Malformation

Masked virus

Masking

Mass median diameter

Mature plant resistance

Mechanical transmission

Median effective concentration

Median latent period

Median lethal dose

Medium volume spraying

Meristem tip

Mist sprayıng

Monogenic resistance

Mosaic

Mottle

Mould covers

Mummification

Mutualism

Mycoherbicide

Mycoplasma

Mycorrhiza

Mycosis

Mycotrophic

Natural immunity

Necrophyte

Necrosis

Necrotic

Necrotroph

Non-persistant virus

Non-virulent

Nosology

Numerical threshold of infection

Obligate parasite

Oligogenic resistance

Parasite

Pathogen

Pathogenicity

Pathotoxin

Patholype

Pelleting

Penetration

Persistence

Persistent virus

Pertophyte

Phyllody

Phylloplane

Physiologic race

Phytiary

Phytoalexin

Phytopathogen

Phytosanitation

Phytotoxemia

Phytotoxicity

Plant pathology

Polygenic resistance

Powdery mildew

Pre-emergence damping-off

Premunity

Primary lesion

Proliferation

Protectant

Protective fungicide

Pure culture

Pustule

Quarantine

Race

Replant disease

Residue

Resistance

Klendusiteiı

Koch se postulate

Latente infeksie

Latente periode

Blaarskroei

Krulblaar, Kroesblaar

Rolblaar

Blaarskroei

Blaarvlek

Letsel

Lignituber

Kleinblaar

Lokale simptome

Laevolumebespuiting

Lise

Masereer

Misvorming

Gemaskeerde virus

Maskering

Massamediaandeursnit

Volwasseplantwecrstand

Meganiese oordrag

Mediaaneffektiewe konsentrasic

Mediaanlatente periode

Mediaanletale dosis

Mediumvolumebespuiting

Meristeempunt

Newelbespuiting

Enkelgeenweerstand

Mosaick

Vlekkerigheid

Oortreksels

Mummilikasie

Wederkerige simbiose

Swamonkruiddoder

Mikoplasma

Mikoris

Mikose

Mikotrofies

Natuurlike immuniteit

Nekroliet

Nekrose

Nekroties

Necrotroof

Verdwynende virus

Avirulent

Nosologie

Besmettingsdrumpelgetal

Verpligte parasiet

Oligogene weerstand

Parasiel

Patogeen

Patogenisitei

Patoloksien

Palotipe

Verpilling

Penetrasic

Nawerking

Blywende virus

Pertofiet

Fillodic

Fillovlak

Fisiologiese ras

Fitiatrie

Fitoaleksien 
Resistint

Relension period

Rhizomorph

Rhizoplane

Rhizosphere

Ring spot

Roguing

Rosctting

Rolting

Run-off

Rust

Safener

Saprophyte

Satellite virus

Scab

Scald

Scorch

Screening host

Staling compound

Seed treatment

Seedling resistance

Semi-persistant virus

Sensitive

Shot hole

Simple interest disease

Slurry treatment

Smut

Soil disinfectant

Soll sterilization

Sooty mould

Specialisation

Specilicity

Spray liquid

Spray material

Spray mixlure

Sprayer

Spraying

Spreader

Sticker

Stigmonosis

Strain

Stunted

Substratum

Suscept
Bestand. Weerstandbiedend

Relensieperiode

Risomorf

Wortclylak

Risosfeer

Kringviek

Altipeverwydering

Rosetvorming

Verrotting

Allowe

Roces

Versagtingsmiddel

Siprofiet

Satcllictvirus

Skurfio

Brandvlek

Skroci

Skeidingsplant

Verseelmiddel

Saadbehundeling

Saailingweerstund

Semiblywende virus

Sensitief

Haclgal

Enkelvoudigerentesiekte

Flodderbehandeling

Brand

Grondontsmettingsmiddel

Grondsterilisasic

Roetskimmel

Spesialisasic

Spesifisiteit

Spuitvloeistof

Spuitmiddel

Spuitmengsel

Spuitapparatat

Bespuiting

Spreimiddel

Kleefmiddel

Stigmonose

Lyn

Verdwerg

Subsiraat

Vathare voedsterplant
Susceptibility

Suspension

Symbiosis

Symptom

Syndrome

Synergism

Systemic agent

Systemic fungicide

Systemic infection

Systenic sympioms

Tixon

Tenacity

Teratogenic

Thermotherapy

Tissue culture

Tolerant

Toxicant

Toxicity

Toxicosis

Toxin

Tracheomycosis

Transmission threshold period

Tumour

Tylosis

Ultra low volume spraying

Vascular wilt disease

Vector

Veinbanding

Veinclearing

Vertical resistance

Viroid

Virulence

Viruliferous

Virus

Virus isolate

Wettable powder

Wetting agent

Wilt

Witches broom

Wound parasite
Vatbaarheid

Suspensic

Simbiose

Simptoom

Sicklebeeld

Sinergisme

Sistemiesc middel

Sistemiese swamdoder

Sistemiese besmetting

Sistemiese simptome

Takson

Kleelvermoe

Teratogenie:

Hitteterapie

Weefiselkultuur

Verdraagsiam

Toksiese middel

Toksisiteit

Toksikose

Toksien

Tracheomikose

Oordragsdrumpelwaarde

Geswel

Tillevorming

Ultralaevolumebespuiting

Vaatbundelverwelksiekte

Vektor

Aarbandchlorose

Aarverheldering

Vertikale weerstand

Viroied

Virulensic

Virusdraend

Virus

Virusisolatat

Benatbare pocier

Benattingsmiddel

Verwelksickle

Heksebesem

Wondparasiet 